This document is the accepted manuscript version of the following article: Hering, J. G., \& Vairavamoorthy, K. (2018). Harvesting experience for sustainable urban water management. In A. K. Biswas, C. Tortajada, \& P. Rohner (Eds.), Assessing global water megatrends (pp. 61-75). Singapore: Springer. http:// doi.org/10.1007/978-981-10-6695-5_4

\title{
Harvesting Experience to Support Sustainable Urban Water Management
}

\author{
Janet G. Hering \\ Eawag, Swiss Federal Institute for Aquatic Science and Technology, CH-8600 Dübendorf, \\ Switzerland \\ Swiss Federal Institute of Technology (ETH) Zürich, IBP, CH-8092 Zürich, Switzerland \\ Swiss Federal Institute of Technology Lausanne (EPFL), ENAC, CH-1015 Lausanne, \\ Switzerland
}

\section{Kalanithy Vairavamoorthy}

IWMI, International Water Management Institute, Battaramulla, Sri Lanka

\begin{abstract}
The urban population exceeded the rural population for the first time in 2007. This megatrend has put increasing stress on urban water supplies and urban water management (UWM). In response to challenges posed by shifting demographics and aging infrastructure in industrialized countries and severe infrastructure deficits in rapidly-growing cities in low- and middle-income countries, sustainable UWM (SUWM) is being developed and implemented. SUWM encompasses a portfolio of approaches that includes: recovery of water, energy and nutrients from wastewater; expansion of potential sources (e.g., stormwater) for water supply; matching water quality (and hence treatment) to intended use, partial system decentralization; and using both "gray" (i.e., fully-engineered) and "green" partiallyengineered infrastructure. To benefit from the expanding experience with SUWM, effective channels are needed for information exchange, which could serve to promote the uptake of practices with demonstrated success. Knowledge platforms should take advantage of recent advances in information technology to combine increased access, reliability and ease of use with responsible curation to ensure the quality of information and avoid conflicts of interest.
\end{abstract}


"The highest research priority is harvesting experience, in the form of comprehensive and detailed case studies, from many more successful communities. We have paid too much attention to barriers - to research problems that have yet to be solved. It's time to pay attention to these success stories. They can inform and inspire action and start new communities down their own unique roads to successful climate adaptation. For these communities, the highest practical priority is to build on what has already worked, not reinvent it."

Prof. Emer. Ron Brunner (Univ. of Colorado)

\section{Introduction}

Although the remarks by Ron Brunner (Rasmussen 2014) in the epigraph to this chapter were made in the context of climate adaptation, they apply equally to issues of sustainable urban water management (SUWM). Despite the crisis mentality that pervades much of the discussion of water resources and water supply, important steps have been taken to identify and implement sustainable solutions. Cities and communities, with their historic responsibilities for water management (Sedlak 2014, Gardner 2016), are already serving as agents of change in conceptualizing, planning and managing the urban water cycle in innovative and more sustainable ways (Suzuki, Dastur et al. 2010, Howe, Vairavamoorthy et al. 2012, OECD 2015). Harvesting experience (i.e., systematically and rigorously validating and documenting examples of success in SUWM) is needed to build a robust evidence base for the implementation of "what has already worked" in new locations so that resources can be directed toward appropriate adaptation to local contexts rather than wholesale reinvention.

The urbanization megatrend is a central driver for improving the sustainability of urban water management (UWM). By building on successful experiences and using existing tools, methods and concepts, urban water managers can capitalize on past investments to address their current and anticipated needs. Local contexts will be decisive in setting priorities and selecting among alternative approaches. In this chapter, we discuss urbanization and its implications for UWM as the background for examining the opportunities to use knowledge platforms more effectively to provide access to the experience, concepts, methods and tools needed to support SUWM.

\section{The urbanization megatrend}

The trend toward increasing urbanization in both more and less developed regions is not a new phenomenon. The rates of urban population growth from 1950- 
1970 were $2 \%$ in more developed regions and $4 \%$ in less developed regions, decreasing to $0.9 \%$ and $3 \%$ in more and less developed regions from 1970 to 2011 (UN 2015). The world urban population exceeded the rural population in 2007; the urbanization trend is expected to continue with most urban growth occurring in low- and middle-income countries, LMICs (Birkmann, Welle et al. 2016, Forman and $\mathrm{Wu} 2016$ ). Most of the world's urban population today reside in urban areas with populations under 300,000 but this fraction is anticipated to decrease. The next most important size class (in terms of the fraction of the world urban population) is medium-sized cities with populations of 1-5 million. Megacities (i.e., populations above 10 million) accounted for $14 \%$ of the world urban population in 2014. Most of the growth in urban population through 2050 is expected to occur in relatively few countries, most notably China, India and Nigeria.

Reflecting the increasing importance of cities, the Sustainable Development Goals (SDGs) include making cities "inclusive, safe resilient and sustainable" as Goal 11 (http://www.un.org/sustainabledevelopment/cities/). Water is included in Goal 11 explicitly in the target to reduce the impact of water-related disasters and implicitly in the target to reduce the adverse per capita impacts of cities. This latter target is explicitly addressed in Goal 6 "Ensure access to water and sanitation for all" (http://www.un.org/sustainabledevelopment/water-and-sanitation/) in the target to "improve water quality by reducing pollution, eliminating dumping and minimizing release of hazardous chemicals and materials, halving the proportion of untreated wastewater and substantially increasing recycling and safe reuse globally".

Throughout history, water management has been a core civic responsibility (Sedlak 2014, Gardner 2016). Given the current and anticipated trends toward increasing urbanization and the vulnerability of freshwater supply (especially in urban areas) (McDonald, Weber et al. 2014, Padowski and Gorelick 2014, Padowski, Gorelick et al. 2015), the issues of UWM are becoming increasing prominent and the need to develop sustainable practices for UWM more obvious. Progress in improving water supply and sanitation in cities in LMICs has not been able to keep pace with urbanization; it is recognized that "improved water sources" per se do not guarantee that water is free from pathogens and lack of trust in the safety of municipal supplies has led to increasing reliance on bottled water as a main drinking water source in some urban areas (WWAP 2015). The need to understand cities as "social-ecological-infrastructural" systems incorporating diverse actors, priorities and alternatives for action is as relevant for the water sector as for other sectors such as transportation, energy supply, building stock and green spaces (Ramaswami, Russell et al. 2016). 


\section{Urban water management}

Given the long history of UWM and its implementation under widely-varying local contexts (Sedlak 2014), it is unsurprising that UWM incorporates many forms and approaches. In modern times, however, conventional UWM is dominated by practices developed in Western Europe and North America, which necessarily reflect those climates and the preponderance of urban settlements on major rivers or coasts. This has led to a conventional paradigm in which water is used for waste conveyance and the rapid conveyance of stormwater away from urban areas to prevent flooding is prioritized. Conventional practice has been strongly oriented toward system centralization and has emphasized the strict separation of drinking water and wastewater to protect human health.

The climates in the countries where the most urban growth is anticipated (i.e., China, India and Nigeria) differ dramatically from those where the conventional UWM paradigms were developed. Water storage in monsoon climates is particularly challenging. Even in Western Europe and North America, the combinations of changing demographics and aging infrastructure pose challenges to conventional UWM practices (OECD 2015). This creates opportunities to consider alternatives to conventional practices both in the end-of-life replacement of infrastructure and in new or expanding urban areas (Farrelly and Brown 2011, Larsen, Hoffmann et al. 2016). Shifting from conventional to sustainable UWM opens new avenues for addressing the vulnerabilities to freshwater supply that cities face (Howe, Vairavamoorthy et al. 2012, McDonald, Weber et al. 2014, Padowski, Gorelick et al. 2015). The development and implementation of SUWM is a response to the urbanization megatrend and the recognized limitations of conventional UWM.

\section{Key aspects of $S U W M$}

In keeping with the meta-principle for sustainable cities that "recognize[s] diverse strategies for resource efficiency in different city types" (Ramaswami, Russell et al. 2016), SUWM encompasses a portfolio of approaches with a focus on the "circular economy" in which the recovery of water, energy and nutrients allows "wastewater" to serve as a resource (Grant, Saphores et al. 2012, Hering, Waite et al. 2013, Larsen, Hoffmann et al. 2016). In addition, SUWM aims to match the quantity and quality of water to its intended use, avoiding the need for the highest level of treatment for all waters. This exposes alternative sources of water (e.g., stormwater) that can be safely used for different purposes, reducing gross water abstraction and water treatment costs. SUWM also breaks away from the paradigm of favoring fully centralized systems to incorporate a continuum of (de)centralization; operation at multiple scales can be addressed through the con- 
cept of polycentricity (van Kerkhoff and Szlezak 2016). Decentralization has the benefit of co-locating treatment and re-use so that (energy) costs associated pumping can be minimized. SUWM relies not only on fully engineered systems (i.e., "gray" infrastructure) but also incorporates partially-engineered systems in which engineering objectives are achieved through natural processes (i.e., "green" infrastructure) (Shuster and Garmestani 2015). Examples include the Green Stormwater Infrastructure (GSI) implemented in the City of Philadelphia, which uses installations including tree trenches, permeable pavement and green roofs to increase stormwater percolation into the soil (National Academies 2016), and the Sponge City program in China (Li, Li et al. 2016).

Implementation of (partially) decentralized systems has several potential benefits. The expensive construction and/or renewal of sewers can be minimized and the demand for water for waste conveyance can be reduced. By avoiding the dilution of waste, the need to treat large volumes of wastewater is also avoided and resource recovery processes can be optimized for high(er) strength "waste". An additional advantage of decentralized systems is their adaptive capacity - the ability to develop in stages and grow incrementally over time, enabling them to better respond to the inherent uncertainties associated with global change pressures (Eckart, Sieker et al. 2010). Their distributed nature also makes them more resilient to the impact and propagation of shocks. It is, however, more difficult to monitor and control performance in (partially) decentralized systems. New technologies (i.e., sensors and control systems) as well as changes in system management and governance are needed to ensure that water quality standards are met (Hering, Waite et al. 2013).

Engagement of stakeholders in planning, decision-making and implementation processes is considered to be an important factor in the success of SUWM. Stakeholder engagement has the potential to break down barriers to information sharing and learning and speed up the identification, development, and uptake of solutions related to urban water management (Butterworth, Batchelor et al. 2009, Howe, Vairavamoorthy et al. 2012). Cities in the U.S. have made major efforts to include stakeholders in planning of sustainable water infrastructure and management, for example in Pittsburgh (National Academies 2016). Stakeholder engagement imposes undeniable transaction costs; strategies to engage stakeholders must address their motivations and efforts are required to bring stakeholders together (Butterworth, McIntyre et al. 2011). Studies in low-income countries indicate that earlier and more intensive participation in Household-centered Environmental Sanitation planning processes conducted in urban areas in Nepal and Lao People's Democratic Republic were associated with greater satisfaction regarding the outcome and implementation as well as higher willingness to pay and to participate in future participatory processes (Luethi and Kraemer 2012). A study of handpump sustainability conducted in rural Ghana underscores the importance of the depth (i.e., intensity) of stakeholder engagement (Marks, Komives et al. 2014). 


\section{SUWM in a development context}

Although urbanization in LMICs poses many challenges, the absence of "lockin" associated with mature infrastructure, governance structures and urban planning also offers opportunities to implement new paradigms for UWM (Brown, Keath et al. 2009, Vairavamoorthy, Eckart et al. 2015). To meet the needs of developing countries, a tailored integrated framework must consider their characteristic water and sanitation practices. The framework must capture the consumption patterns from yard taps, private wells, water kiosks and private water vendors and account for intermittent supply, high leakage and low pressure conditions in water distribution systems (where they exist). Even where adequate water treatment is provided at the treatment plant, intermittent supply and low water pressure allow seepage of chemical and microbial contaminants into the distribution system resulting in the deterioration of water quality. The variety of different on-site and off-site sanitation options such as pit latrines and septic tanks must also be included as well as the pollution of potential water sources resulting from poor sanitation and the (common) absence of wastewater treatment. An additional consideration is the use of wastewater for irrigation of urban agriculture, which has the advantage that the scarce water resources are used multiple times but increases public health risks by spreading the pathogens along the food chain (Qadir, Wichelns et al. 2010, Liebe and Ardakanian 2013). Nonetheless, market-driven crop production on urban open spaces can be both highly productive and profitable (Drechsel and Dongus 2010). Possible constraints on SUWM practices resulting from other urban development (e.g., reduced opportunities for stormwater infiltration associated an increase in impermeable surfaces) must also be considered.

\section{SUWM concepts, networks and tools}

Urban sustainability, including SUWM, is an increasing focus of attention in cities world-wide (National Academies 2016). Information on the concepts, networks and tools that have been developed and are being implemented as well as the experience gained through the implementation of SUWM practices needs to be made accessible and usable to support expanded uptake of SUWM.

\section{Concepts}

Like all efforts to improve sustainability, SUWM recognizes that measures to improve human welfare will ultimately be self-defeating if they result in the impairment of critical ecosystem functions. By dealing with cities as "socialecological-infrastructural” systems (Ramaswami, Russell et al. 2016), SUWM can account for the combination of natural, technical and societal factors that contrib- 
ute both to pressures on the water environment and the capacity for SUWM (Figure 1). In this framework, it is clear that deficits in one type of factor, such as limited natural water availability, could be offset by demand management and/or infrastructure for water storage or aggravated by inadequate human capacity and economic resources. Similarly, demand, endowment, infrastructure and governance "characteristics" were identified in an analysis of freshwater vulnerability (Padowski, Gorelick et al. 2015). It must also be recognized that the water footprint of cities extends well beyond the urban boundary due to both water conveyance and the transport of virtual water in agricultural products (Hoff, Doell et al. 2014, McDonald, Weber et al. 2014, OECD 2015, Paterson, Rushforth et al. 2015).

SUWM shares some of its theoretical underpinnings with integrated UWM (IUWM) (Bahr 2012), in particular, the "one water" practice of managing all of the elements of water supply, stormwater, and wastewater as an integrated, (ideally-)closed loop. The main difference is that, in SUWM, integration is considered as a means to the end goal of sustainability, rather than as an end in itself. Integration can bring substantial benefits but also carries transaction costs and may be infeasible when boundaries of formal authority are not compatible with integration (Hering, Hoehn et al. 2012, Hering and Ingold 2012). Nonetheless, the principles that inform IUWM and, more generally, integrated water resources management (IWRM) are also broadly applicable to SUWM. A variety of case studies have also been conducted (see also the sub-section Tools below), but the generalizations that would link the overarching principles with specific applications are often lacking. This is illustrated schematically in Figure 2, in which specific measures (level "WHAT") developed on an ad hoc basis in a local context would ideally be linked to the overarching goals and principles (level "WHY") through general and generalizable concepts (level "HOW").

\section{Networks}

Cities have already established networks related to resource management and environmental issues, particularly climate change adaptation. Two wellestablished examples are the International Council for Local Environmental Initiatives (http://www.iclei.org/), which was founded in 1990 by 200 local governments from 43 countries, and the broader United Cities and Local Governments (http://www.uclg.org/) founded in 2004. About 10 years ago, the organization C40 Cities (http://www.c40.org/) was established to bring the largest cities (especially the megacities) together to focus on climate change adaptation. This group now includes over 80 of the largest cities world-wide. In 2013, the organization 100 Resilient Cities (http://www.100resilientcities.org/\#/- $/$ ) initiated activities with a first cohort of 32 cities to develop roadmaps for resilience. Although water management, per se, is not a major focus for any of these organizations, C40 Cities recently partnered with the Nature Conservancy and the International Water 
Association (IWA) to develop an Urban Water Blueprint (McDonald and Shemie 2014). A specialized network of water operators (http://gwopa.org/en/) has been established to share information and good practices in water supply. Consensus documents related to urban water management have been signed at the World Water Forum (WWF 2009). Conferences serve as an important venue for information exchange and support of mutual interests. Conferences focusing on urban issues include: the International Making Cities Livable Conference (http://www.livablecities.org/), the Mistra Urban Futures Conference (http://www.mistraurbanfutures.org/en), the Urbanization and Global Environmental Change Conference (http://www.ugec2014.org/), and the World Urban Forum (http://unhabitat.org/wuf/).

\section{Tools}

A variety of tools relevant to SUWM have been developed. Some of these address more general issues of urban resilience, often focusing on identifying indicators for sustainability and/or resilience (Suzuki, Dastur et al. 2010, Science for Environment Policy 2015, National Academies 2016). Specifically for the water sector, OECD reports provide an overview of issues related to financing, diffusion of innovations and urban-rural cooperation (OECD 2015) as well as a list of links related to water governance (OECD 2014). Water footprint analysis and related methods (e.g., life cycle assessment) have been applied to assess water sustainability of urban regions, particularly related to consumption; this highlights the urban impact on remote regions through the import of virtual water (Hoff, Doell et al. 2014, Paterson, Rushforth et al. 2015). City water maps have been used to characterize the dependence and stress on urban water supplies, highlighting the physical conveyance of water from (sometimes remote) watersheds (McDonald, Weber et al. 2014). Models developed for IUWM, which include all urban water flows (blue, white, grey and black water) as well as their integration through recycling schemes (Bach, Rauch et al. 2014), are also applicable for SUWM. These models are generally water balancing models that provide a structured approach to identify a portfolio of water sources, prioritize their selection, and assess water flows and contaminant fluxes within an IUWM strategy and can be used to investigate alternative water management strategies. The City Blueprint Index was developed to characterize performance of cities using a variety of indicators directly and indirectly related to water management (Koop and van Leeuwen 2015, Koop and van Leeuwen 2015, Van Leeuwen, Koop et al. 2016). The Urban Water Blueprint provides information on measures that have been or could be used to improve the sustainability of UWM (McDonald and Shemie 2014). Measures to decouple the degradation of water resources (including water pollution) from economic growth are described in a recent UNEP report (UNEP 2015). For the challenging issue of sanitation management in LMICs, SFDs (Shit Flow Diagrams) provide a visualization of safely and unsafely managed excreta (http://sfd.susana.org/). The elabo- 
ration of indicators for SGD targets also provides definitions and tools for water and sanitation under Goal 6 (https://www.wssinfo.org/sdg-baselines/). Examples of resource toolboxes are listed in Table 1.

\section{Knowledge platforms to support SUWM}

Many of the resources and networks discussed above are web-based, offering potential access to a wide range of options for SUWM. Some of the existing platforms (e.g., the 100RC Platform and Watershare ${ }^{\circledR}$ ) are intended to facilitate exchange among partners and/or members. It would be difficult to claim, however, that the existing platforms are optimally structured to promote uptake of practices with demonstrated effectiveness. In addition, the sheer number of platforms is daunting and exacerbated by the lack of effective cross-referencing among them.

Ideally, knowledge platforms would be structured to guide prospective users intuitively through the available information with an interface that supports interactive queries. In the specialized area of sanitation systems and technologies, an example of this approach is the eCompendium (http://ecompendium.sswm.info/). In this interactive tool, users can design sanitation systems using templates with reference to standardized technology information sheets.

Similarly, a web resource provides support for water treatment plant design; detailed plans for the design of coagulation/flocculation plants can be modified for implementation (https://confluence.cornell.edu/display/AGUACLARA/Home). This is supported by online access to (near) real-time information on the performance of constructed treatment facilities (http://monitor.wash4all.org/).

A new resource now being finalized is the IUWM Tool Kit (Fig. 3). The Diagnostic Tool, in particular, provides a standardized process for analyzing UWM sub-systems and bench-marking performance metrics. This could also serve as the basis for harvesting experience on specific SUWM applications.

With the megatrend of rapid advances in information technology, knowledge platforms should offer increasing access, reliability and ease of use; responsible curation is needed to ensure the quality of information and to avoid conflicts of interest. As new platforms emerge, for example the "mobilize" platform being developed by the Sustainable Development Solutions Network (http://unsdsn.org/), the "open network" being developed by Future Earth (http://www.futureearth.org/) and the online platform being developed by the United Nations (UN) Technology Facilitation Mechanism (https://sustainabledevelopment.un.org/TFM), it will be important that some leveraging of efforts (at the very least, cross-referencing) is incorporated. A federated approach could help to create shared ownership (and credit), mitigating the effects of the "not-invented-here syndrome". Web resources should be designed to allow expansion for data sharing and reuse across application, enterprise, and community boundaries (i.e., the semantic web) as illustrated by the Global Water Platform (http://www.globalwaterplatform.org/). 
This is needed to support data mining and machine learning. It will also be necessary to support co-production of knowledge, which bridges the gap between experience-based and research-based knowledge (Cash, Adger et al. 2006, Pohl 2008, Pahl-Wostl, Voeroesmarty et al. 2013) to allow the integration of "high- and vernacular technologies" (Ramaswami, Russell et al. 2016). Lastly, knowledge must be redefined as a global public good rather than a private asset (van Kerkhoff 2013).

\section{Outlook and recommendations}

There is a strong momentum for the transition from conventional to sustainable UWM. Opportunities are created in industrialized countries by the need to accommodate changing demographics and replace aging infrastructure and, in LMICs, by the urbanization megatrend and the need to provide services for new and expanding urban areas. Researchers have developed concepts and tools to support the transition to sustainability, some of which, like the SWITCH Transition Manual (Jefferies and Duffy 2011), are the products of joint projects with cities, their water managers and stakeholders. Cities have also taken the lead in incorporating SUWM into their planning, implementing (more) sustainable practices and creating and participating in networks intended to promote the sharing of experience-based knowledge (National Academies 2016). They are supported in this endeavor by boundary organizations (like 100 Resilient Cities) that can link research- and evidence-based knowledge, increasing the salience, credibility and legitimacy of co-produced knowledge (Cash, Clark et al. 2003). This is particularly important to offset the tendency of "lessons being lost", which reflects the fact that often neither program managers or funding agencies have a primary interest in capturing lessons from experience and/or codifying them in best-practice repositories (van Kerkhoff and Szlezak 2016). Academic researchers could play an important role in supporting these efforts and also in merging SUWM content knowledge with forefront information technology. This is urgently needed to help build the next generation of knowledge platforms to support SUWM and achieve the goal of moving "from data to information to knowledge and, ultimately, to action for urban sustainability and human well-being" (Ramaswami, Russell et al. 2016). 
Table 1. Examples of resource toolboxes relevant to SUWM

\begin{tabular}{|c|c|c|c|}
\hline name & organization(s) & comments & URL \\
\hline 100 RC Platform & 100 Resilient Cities & $\begin{array}{l}\text { Curated suite of resilience-building tools and services, } \\
\text { provided by partners from the private, public, academ- } \\
\text { ic, and non-profit sectors }\end{array}$ & $\begin{array}{l}\text { http://www.100resilientci } \\
\text { ties.org/partners\#/-_ I }\end{array}$ \\
\hline $\begin{array}{l}\text { Effective Utility Man- } \\
\text { agement Resource } \\
\text { Toolbox }\end{array}$ & $\begin{array}{l}\text { American Public Works Association, } \\
\text { American Water Works Association, As- } \\
\text { sociation of Metropolitan Water Agen- } \\
\text { cies, National Association of Clean Water } \\
\text { Agencies, National Association of Water } \\
\text { Companies, Water Environment Federa- } \\
\text { tion, U.S. Environmental Protection } \\
\text { Agency (EPA) }\end{array}$ & $\begin{array}{l}\text { Intended to support effective utility management col- } \\
\text { lectively and individually throughout the water sector } \\
\text { and to develop a joint strategy to identify, encourage, } \\
\text { and recognize excellence in water and wastewater util- } \\
\text { ity management }\end{array}$ & $\begin{array}{l}\text { http://www.watereum.org } \\
\text { /resources/resource- } \\
\underline{\text { toolbox/ }}\end{array}$ \\
\hline IWRM Toolbox & Global Water Partnership & $\begin{array}{l}\text { A free and open database with a library of background } \\
\text { papers, policy briefs, technical briefs and perspective } \\
\text { papers as well as huge sections of case studies and ref- } \\
\text { erences in each tool }\end{array}$ & $\begin{array}{l}\text { http://www.gwp.org/en/T } \\
\text { oolBox/ }\end{array}$ \\
\hline $\begin{array}{l}\text { Leaders Innovation } \\
\text { Forum for Technology }\end{array}$ & $\begin{array}{l}\text { Water Environment Research Foundation; } \\
\text { Water Environment Federation }\end{array}$ & $\begin{array}{l}\text { Intended to help bring new water technology to the } \\
\text { field quickly and efficiently }\end{array}$ & http://www.werf.org/lift \\
\hline $\begin{array}{l}\text { Sustainable Sanitation } \\
\text { and Water Manage- } \\
\text { ment Toolbox }\end{array}$ & seecon gmbh & $\begin{array}{l}\text { The Toolbox contains: background on environmental, } \\
\text { economic and socio-cultural issues; factsheets and } \\
\text { presentations of tools for Planning and Processing and } \\
\text { for Implementation, "min-toolboxes" on specific top- } \\
\text { ics, training material, library and glossary }\end{array}$ & http://www.sswm.info/ \\
\hline Toolbox & UN Water & $\begin{array}{l}\text { Gathers existing practical guidance which could be } \\
\text { useful for the implementation of the different targets } \\
\text { proposed for the water related SDGs }\end{array}$ & $\begin{array}{l}\mathrm{http}: / / \text { watersdgtoolbox.or } \\
\mathrm{g} /\end{array}$ \\
\hline Watershare ${ }^{\circledR}$ & $\begin{array}{l}\text { Membership organization led by KWR } \\
\text { Watercycle Research Institute }\end{array}$ & $\begin{array}{l}\text { Selected partner knowledge institutes from all over the } \\
\text { world share in the use of expert water-related tools }\end{array}$ & $\begin{array}{l}\text { https://www.watershare.e } \\
\underline{\mathrm{u} /}\end{array}$ \\
\hline
\end{tabular}


Fig. 1. Overlapping contributions of natural, societal and technical factors to the capacity for sustainable water management.

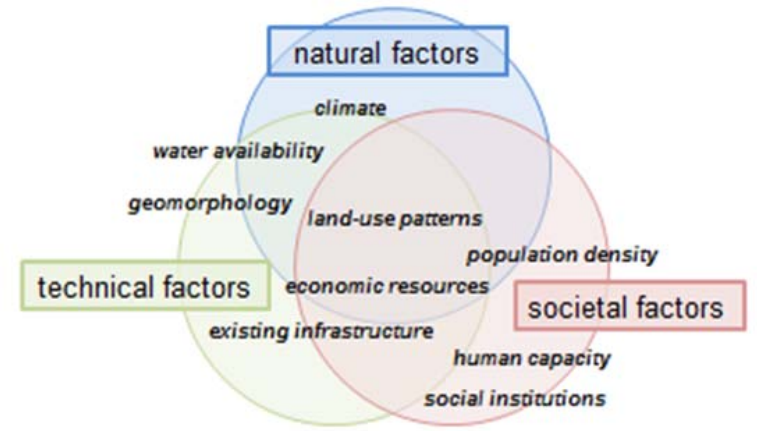

Fig. 2. Schematic illustration of levels of conceptual organization from the overarching ("WHY") to the concrete ("WHAT"). The intermediate level that links these ("HOW") is often neglected.

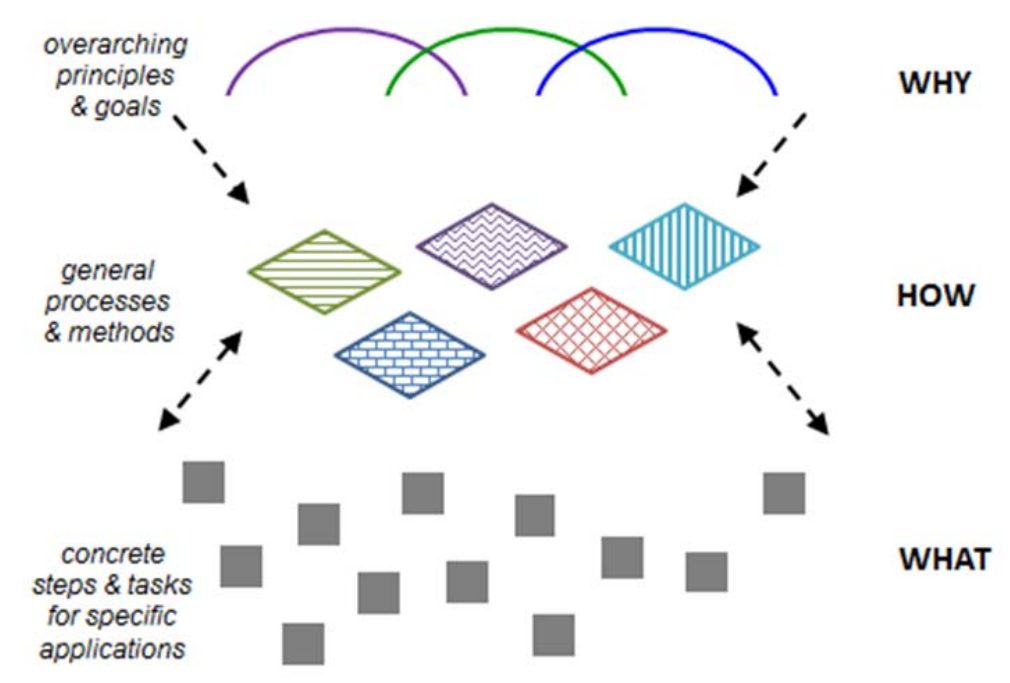


Fig. 3. Home page for the IUWM Tool Kit developed by the Global Water Partnership (GWP), the University of South Florida, the International Water Management Institute (IWMI) and the Water Partnership Program of the World Bank (PCGS, GWP et al. 2015). Release is anticipated in 2017.

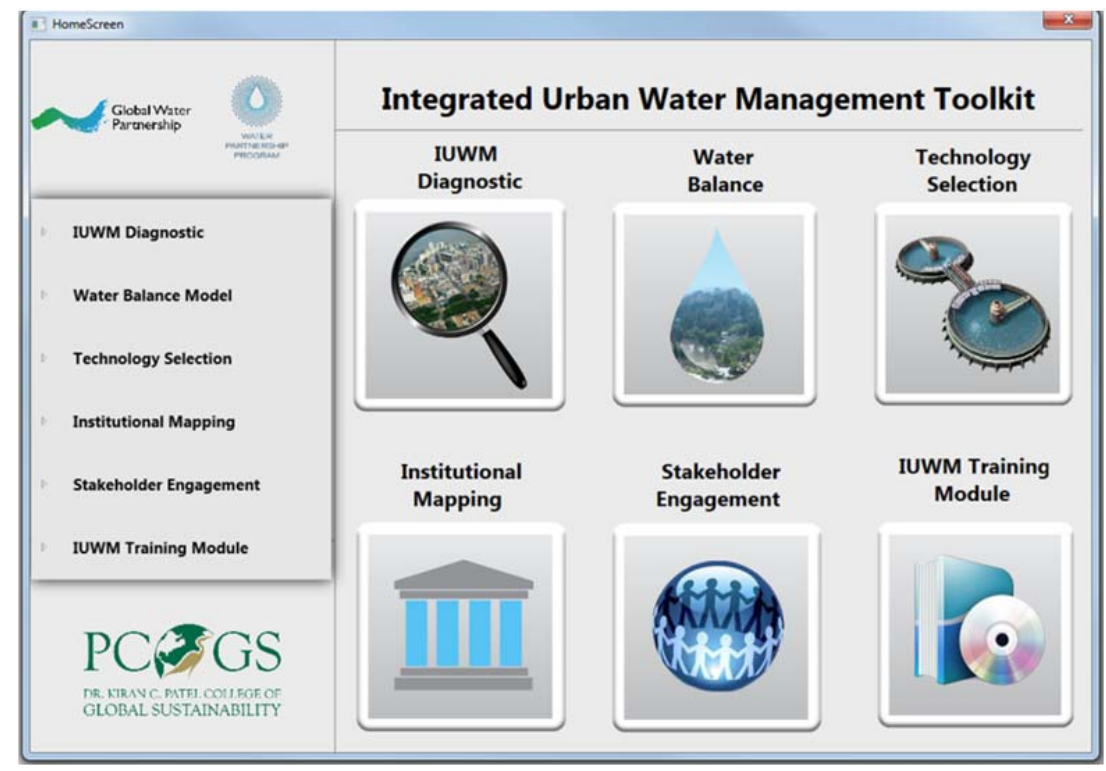




\section{References}

Bach PM, Rauch W, Mikkelsen PS, McCarthy DT and Deletic A (2014) A critical review of integrated urban water modelling: Urban drainage and beyond. Environmental Modelling \& Software 54:88-107. doi:10.1016/j.envsoft.2013.12.018

Bahr A (2012) Integrated Urban Water Management. Global Water Partnership, Technical Committee,

85 , http:/www.gwp.org/Global/ToolBox/Publications/Background\%20paper s/16\%20Integrated $\% 20$ Urban $\% 20$ Water $\% 20$ Management $\% 20(2012)$.pdf

Birkmann J, Welle T, Solecki W, Lwasa S and Garschagen M (2016) Boost resilience of small and mid-sized cities. Nature 537 (7622):605-608. doi: $10.1038 / 537605 \mathrm{a}$

Brown RR, Keath N and Wong THF (2009) Urban water management in cities: historical, current and future regimes. Water Science and Technology 59 (5):847-855. doi:10.2166/wst.2009.029

Butterworth J, McIntyre P and da Silva Wells C (eds) (2011) SWITCH in the city: putting urban water management to the test, http://www.switchurbanwater.eu/outputs/pdfs/SWITCH in the city.pdf. IRC International Water and Sanitation Centre, The Hague, The Netherlands

Butterworth JA, Batchelor C, Moriarty P, Schouten T, Da Silva C, Verhagen J, Bury PJ, Sutherland A, Manning N, Darteh B, Dziegielewska-Geitz M and Eckart J (2009) Building more effective partnerships for innovation in urban water management. In: J. Feyen, K. Shannon and M. Neville (eds) Water and Urban Development Paradigms. pp 557-565

Cash DW, Adger WN, Berkes F, Garden P, Lebel L, Olsson P, Pritchard L and Young O (2006) Scale and cross-scale dynamics: Governance and information in a multilevel world. Ecology and Society 11 (2):8, http://www.ecologyandsociety.org/vol11/iss2/art8/

Cash DW, Clark WC, Alcock F, Dickson NM, Eckley N, Guston DH, Jager J and Mitchell RB (2003) Knowledge systems for sustainable development. Proceedings of the National Academy of Sciences of the United States of America 100 (14):8086-8091. doi:10.1073/pnas.1231332100

Drechsel P and Dongus S (2010) Dynamics and sustainability of urban agriculture: examples from sub-Saharan Africa. Sustainability Science 5 (1):69-78. doi:10.1007/s11625-009-0097-x

Eckart J, Sieker H and Vairavamoorthy K (2010) Flexible Urban Drainage Systems. Water Practice and Technology 5 (4). doi:10.2166/wpt.2010.072

Farrelly M and Brown R (2011) Rethinking urban water management: Experimentation as a way forward? Global Environmental Change- 
$\begin{array}{llll}\text { Human and Policy Dimensions } & 21 & \text { (2):721-732. }\end{array}$ doi:10.1016/j.gloenvcha.2011.01.007

Forman RTT and Wu J (2016) Where to put the next billion people. Nature 537 (7622):608-611. doi:10.1038/537608a

Gardner G (2016) The City: A System of Systems. In: G. Gardner, T. Prugh and M. Renner (eds) Can a City Be Sustainable? State of the World (2016). Island Press, Washington, DC, pp 27-44

Grant SB, Saphores J-D, Feldman DL, Hamilton AJ, Fletcher TD, Cook PLM, Stewardson M, Sanders BF, Levin LA, Ambrose RF, Deletic A, Brown R, Jiang SC, Rosso D, Cooper WJ and Marusic I (2012) Taking the "Waste" Out of "Wastewater" for Human Water Security and Ecosystem Sustainability. Science 337 (6095):681-686. doi:10.1126/science. 1216852

Hering JG, Hoehn E, Klinke A, Maurer M, Peter A, Reichert P, Robinson C, Schirmer K, Schirmer M, Stamm C and Wehrli B (2012) Moving Targets, Long-Lived Infrastructure, and Increasing Needs for Integration and Adaptation in Water Management: An Illustration from Switzerland. Environmental Science \& Technology $46 \quad$ (1):112-118. doi:10.1021/es202189s

Hering JG and Ingold KM (2012) Water Resources Management: What Should Be Integrated? Science 336 (6086):1234-1235. doi:10.1126/science.1218230

Hering JG, Waite TD, Luthy RG, Drewes JE and Sedlak DL (2013) A Changing Framework for Urban Water Systems. Environmental Science \& Technology 47 (19):10721-10726. doi:10.1021/es4007096

Hoff H, Doell P, Fader M, Gerten D, Hauser S and Siebert S (2014) Water footprints of cities - indicators for sustainable consumption and production. Hydrology and Earth System Sciences 18 (1):213-226. doi:10.5194/hess-18-213-2014

Howe CA, Vairavamoorthy K and van der Steen NP (eds) (2012) SWITCH Sustainable Water Management in the City of the Future (Final Report), http://www.switchurbanwater.eu/outputs/pdfs/SWITCH Final Report.pdf. UNESCO-IHE, Delft

Jefferies C and Duffy A (2011) SWITCH Transition Manual. University of Abertay, 145, $\quad$ http://www.switchurbanwater.eu/outputs/pdfs/W13 GEN MAN D1.3.4 SWITCH Transition Manual.pdf

Koop SHA and van Leeuwen CJ (2015) Application of the Improved City Blueprint Framework in 45 Municipalities and Regions. Water Resources Management 29 (13):4629-4647. doi:10.1007/s11269-015-1079-7

Koop SHA and van Leeuwen CJ (2015) Assessment of the Sustainability of Water Resources Management: A Critical Review of the City Blueprint Approach. Water Resources Management 29 (15):5649-5670. doi:10.1007/s11269-015-1139-Z 
Larsen TA, Hoffmann S, Luthi C, Truffer B and Maurer M (2016) Emerging solutions to the water challenges of an urbanizing world. Science 352 (6288):928-933. doi:10.1126/science.aad8641

Li X, Li J, Fang X, Gong Y and Wang W (2016) Case Studies of the Sponge City Program in China. World Environmental and Water Resources Congress 2016, ASCE, West Palm Beach, Florida. doi:10.1061/9780784479858.031

Liebe J and Ardakanian R (eds) (2013) Proceedings of the UN-Water project on the Safe Use of Wastewater in Agriculture, http://www.ais.unwater.org/ais/pluginfile.php/62/course/section/29/proce edings-no-11_WEB.pdf. Proceedings Series No. 11. UNW-DPC Bonn

Luethi C and Kraemer S (2012) User perceptions of participatory planning in urban environmental sanitation. Journal of Water Sanitation and Hygiene for Development 2 (3):157-167. doi:10.2166/washdev.2012.077

Marks SJ, Komives K and Davis J (2014) Community Participation and Water Supply Sustainability: Evidence from Handpump Projects in Rural Ghana. Journal of Planning Education and Research 34 (3):276-286. doi:10.1177/0739456x14527620

McDonald RI and Shemie D (2014) Urban Water Blueprint: Mapping conservation solutions to the global water challenge. The Nature Conservancy, 100, http://water.nature.org/waterblueprint/\#/intro=true

McDonald RI, Weber K, Padowski J, Floerke M, Schneider C, Green PA, Gleeson T, Eckman S, Lehner B, Balk D, Boucher T, Grill G and Montgomery M (2014) Water on an urban planet: Urbanization and the reach of urban water infrastructure. Global Environmental Change-Human and Policy Dimensions 27:96-105. doi:10.1016/j.gloenvcha.2014.04.022

National Academies (2016) Pathways to Urban Sustainability: Challenges and Opportunities for the United States, The National Academies Press, Washington, DC. doi:10.17226/23551

OECD (2014) Inventory: Existing Tools, Practices and Guidelines to Foster Governance in the Water Sector. OECD, 31, http://www.oecd.org/gov/regional-policy/inventory.pdf

OECD (2015) Water and Cities: Ensuring Sustainable Futures. 178 pp. doi:10.1787/9789264230149-en

Padowski JC and Gorelick SM (2014) Global analysis of urban surface water supply vulnerability (vol 9, 104004, 2014). Environmental Research Letters 9 (11). doi:10.1088/1748-9326/9/11/119501

Padowski JC, Gorelick SM, Thompson BH, Rozelle S and Fendorf S (2015) Assessment of human-natural system characteristics influencing global freshwater supply vulnerability. Environmental Research Letters 10 (10). doi:10.1088/1748-9326/10/10/104014

Pahl-Wostl C, Voeroesmarty C, Bhaduri A, Bogardi J, Rockstroem J and Alcamo J (2013) Towards a sustainable water future: shaping the next decade of 
global water research. Current Opinion in Environmental Sustainability 5 (6):708-714. doi:10.1016/j.cosust.2013.10.012

Paterson W, Rushforth R, Ruddell BL, Konar M, Ahams IC, Gironas J, Mijic A and Mejia A (2015) Water Footprint of Cities: A Review and Suggestions for Future Research. Sustainability 7 (7):8461-8490. doi:10.3390/su7078461

PCGS, GWP, WB and IWMI (2015) Integrated Urban Water Management Toolkit (Computer Software and Guidance Tools). A Training Package and Planning Tools for Integrated Urban Water Management. University of South Florida,

Pohl C (2008) From science to policy through transdisciplinary research. Environmental Science \& Policy 11 (1):46-53. doi:10.1016/j.envsci.2007.06.001

Qadir M, Wichelns D, Raschid-Sally L, McCornick PG, Drechsel P, Bahri A and Minhas PS (2010) The challenges of wastewater irrigation in developing countries. Agricultural Water Management 97 (4):561-568. doi:10.1016/j.agwat.2008.11.004

Ramaswami A, Russell AG, Culligan PJ, Sharma KR and Kumar E (2016) Metaprinciples for developing smart, sustainable, and healthy cities. Science 352 (6288):940-943. doi:10.1126/science.aaf7160

Rasmussen C (2014) Just 5 questions: Community initiatives against climate change. NASA. http://climate.nasa.gov/news/1026/just-5-questionscommunity-initiatives-against-climate-change/. Accessed July 152016

Science for Environment Policy (2015) Indicators for sustainable cities. European $\begin{array}{lll}\text { Commission } & \text { DG } & \text { Environment, }\end{array}$ http://ec.europa.eu/environment/integration/research/newsalert/pdf/indica tors_for_sustainable cities_IR12_en.pdf

Sedlak D (2014) Water 4.0: The Past, Present, and Future of the World's Most Vital Resource. Yale University Press New Haven

Shuster WD and Garmestani AS (2015) Adaptive exchange of capitals in urban water resources management: an approach to sustainability? Clean Technologies and Environmental Policy 17 (6):1393-1400. doi:10.1007/s10098-014-0886-5

Suzuki H, Dastur A, Moffatt S, Yabuki N and Maruyama H (2010) Eco2 Cities: Ecological Cities as Economic Cities. The World Bank, 358, http://siteresources.worldbank.org/INTURBANDEVELOPMENT/Resou rces/336387-1270074782769/Eco2_Cities_Book.pdf

UN (2015) World Urbanization Prospects: The 2014 Revision. United Nations, Department of Economic and Social Affairs, Population Division, ST/ESA/SER.A/366,

493 , https://esa.un.org/unpd/wup/Publications/Files/WUP2014-Report.pdf

UNEP (2015) Options for decoupling economic growth from water use and water pollution. International Resource Panel Working Group on Sustainable Water 
http://www.unep.org/resourcepanel/KnowledgeResources/AssessmentAr easReports/Water/tabid/133332/Default.aspx

Vairavamoorthy K, Eckart J, Tsegaye S, Ghebremichael K and Khatri K (2015) A Paradigm Shift in Urban Water Management: An Imperative to Achieve Sustainability. In: S. G. Setegn and M. C. Donoso (eds) Sustainability of Integrated Water Resources Management: Water Governance, Climate and Ecohydrology, 10.1007/978-3-319-12194-9_4. Springer International Publishing, Cham, pp 51-64. doi:10.1007/978-3-319-12194-9_4

van Kerkhoff L (2013) Knowledge Governance for Sustainable Development: A Review. Challenges in Sustainability 1 (2):82-93. doi:10.12924/cis2013.01020082

van Kerkhoff L and Szlezak NA (2016) The role of innovative global institutions in linking knowledge and action. Proceedings of the National Academy of Sciences of the United States of America 113 (17):4603-4608. doi:10.1073/pnas.0900541107

Van Leeuwen CJ, Koop SHA and Sjerps RMA (2016) City Blueprints: baseline assessments of water management and climate change in 45 cities. Environment, Development and Sustainability 18 (4):1113-1128. doi:10.1007/s10668-015-9691-5

WWAP (2015) The United Nations World Water Development Report 2015: Water for a Sustainable World. UNESCO, 122, http://unesdoc.unesco.org/images/0023/002318/231823E.pdf

WWF (2009) Istanbul Water Consensus For Local and Regional Authorities World Water Forum. http://www.worldwatercouncil.org/fileadmin/world water council/docu ments_old/World_Water_Forum/WWF5/Istanbul_Water_Consensus_En g_Final.pdf. Accessed August 132016 